\title{
Genetic Divergence Analysis in Cowpea [Vigna unguiculata (L.) Walp.]
}

\author{
Navreet Kaur Rai*, A. K. Sharma, A. K. Parihar, Sangeeta Pal and Ravina Beniwal \\ Department of Genetics and Plant Breeding, College of Agriculture, SKRAU, Bikaner, India \\ *Corresponding author
}

\begin{abstract}
A B S T R A C T
\section{Keywords}

Genetic divergence, Mahalanobis $\mathrm{D}^{2}$ statistic, Tocher's method

Article Info

Accepted:

16 November 2020

Available Online:

10 December 2020

Thirty cowpea genotypes were investigated to analyse the genetic divergence for twelve characters. These genotypes were clustered into 8 distinct groups using Mahalanobis $\mathrm{D}^{2}$ statistic and Tocher's method. Cluster I and cluster II were the largest comprised of 12 genotypes each. Cluster III, IV, V, VI, VII and VIII were monogenotypic indicating wide diversity from the rest and also from each other. The maximum intra cluster $\mathrm{D}^{2}$ value was observed within cluster II followed by cluster I suggesting that genotypes present in these clusters might have different genetical constitution. The highest inter cluster distance was registered between cluster II and cluster III followed by cluster II and cluster V and cluster II and cluster IV indicating wide divergence among these clusters. The crossing among the genotypes of these divergent clusters could be used in hybrid development programme of cowpea.
\end{abstract}

\section{Introduction}

Cowpea is a valuable and cheapest source of plant derived proteins, minerals, vitamins and other substitutes. This crop is widely cultivated in semi-arid and arid regions of the world. It is a drought-hardy, vigrously growing and shade providing crop which makes it suitable for growing in regions like Bikaner and other parts of Rajasthan. As this crop provides a shielding effect to the soil it helps in conserving soil moisture in rainfed areas. Green pods of cowpea are used as vegetable and dried seeds are used in making dal, flour, biscuits and many more other edible products. As a fodder, it is also proved to be a great source of protein and other health minerals for ruminants in arid regions.
Mahalanobis $\mathrm{D}^{2}$ analysis is a numerical approach that is used for the assessment of genetic diversity in plant breeding. It helps in the selection of genetically divergent parents in hybridization programmes. This technique can evaluate a large number of germplasm lines at a time for genetic diversity.

\section{Materials and Methods}

The experiment was carried out during kharif2019 to analyse genetic divergence in 30 genotypes of cowpea on Research Farm of College of Agriculture, Bikaner for 12 quantitative characters. The thirty genotypes were classified into clusters using Mahalanobis $\mathrm{D}^{2}$ analysis and Tocher's method. Test of differences between mean 
values of a number of correlated variables was done as described by Rao (1952). Average intra and inter cluster distances were also evaluated.

\section{Results and Discussion}

Based on genetic divergence and magnitude of $\mathrm{D}^{2}$ values, these 30 genotypes were classified into 8 distinct clusters (Table 1). Cluster I and II were the largest clusters comprised of 12 genotypes each. Cluster III, IV, V, VI, VII and VIII were monogenotypic indicating wide diversity from the rest and also from each other. The present outcomes are in accordance with the results of Vavilapalli et al., (2014) classified 32 genotypes of cowpea into 6 clusters; Jogdhande et al., (2016) accounted 30 genotypes of cowpea into 6 clusters; Praveena et al., (2019) distributed 30 genotypes of cowpea into eleven clusters.
The intra cluster distance $\left(\mathrm{D}^{2}\right)$ ranged from zero to 198.48 . Inter cluster distance $\left(\mathrm{D}^{2}\right)$ was between 125.62 and 1437.00 (Table 2). The maximum intra cluster distance was observed within cluster II $\left(D^{2}=198.48\right)$ followed by cluster I $\left(\mathrm{D}^{2}=153.14\right)$. The clusters III, IV, V, VI, VII, VIII recorded no intra cluster distance $\left(D^{2}=0\right)$ due to their monogenotypic nature. The highest inter cluster distance was observed among cluster II and cluster III $\left(\mathrm{D}^{2}=\right.$ 1437.00) followed by cluster II and cluster V $\left(\mathrm{D}^{2}=1385.10\right)$ and cluster II and cluster IV $\left(\mathrm{D}^{2}=1148.80\right)$.

The results showed that range of mean values was of wider divergence for the traits like plant height and biological yield per plant and narrow divergence for the characters such as days to maturity, number of branches per plant, number of seeds per pod and protein content (Table 3).

Table.1 Cluster composition in cowpea

\begin{tabular}{|c|c|l|l|}
\hline Cluster & $\begin{array}{l}\text { Number of } \\
\text { genotypes }\end{array}$ & \multicolumn{1}{|c|}{ Name of genotypes } & \multicolumn{1}{|c|}{ Significant characteristics of the cluster } \\
\hline I & 12 & $\begin{array}{l}\text { PCP-11131, VCP-13-001, C-152, RC-101, Phaguni } \\
\text { Navjyot-21, Arka Garima, PGCP-67, PCP-1118, TVX- } \\
944, \text { VCP-12-005, Pant Lobia-4, Pusa Komal Abhinav- } \\
41\end{array}$ & $\begin{array}{l}\text { Medium height, more number of seeds per pod } \\
\text { and highest protein content }\end{array}$ \\
\hline II & 12 & $\begin{array}{l}\text { CPD-293, Pant Lobia-3, Parvati AV-89, Vardhan-25, } \\
\text { GC-1603, SKAU-C-407, GC-3, BCP-5, PCP-306-1, } \\
\text { GC-1612, CH-46, Bidoli Local }\end{array}$ & $\begin{array}{l}\text { Maximum plant height, adequate number of } \\
\text { pods per plant and highest protein content }\end{array}$ \\
\hline III & 1 & Sadabahar-12 & $\begin{array}{l}\text { Late maturity, small plant height, maximum } \\
\text { number of branches per plant and maximum } \\
\text { number of pods per plant }\end{array}$ \\
\hline IV & 1 & PGCP-68 & $\begin{array}{l}\text { Early maturity, more harvest index and good } \\
\text { seed yield }\end{array}$ \\
\hline V & 1 & Kashi Kanchan & $\begin{array}{l}\text { Late maturity, smallest in plant height and } \\
\text { maximum pod length }\end{array}$ \\
\hline VI & 1 & GC-6 & $\begin{array}{l}\text { Early flowering, early maturity, maximum } \\
\text { seeds per pod and highest biological yield }\end{array}$ \\
\hline VII & 1 & KBC-2 & $\begin{array}{l}\text { Late flowering, Late maturity, minimum } \\
\text { number of branches, more biological yield }\end{array}$ \\
\hline VIII & 1 & TC-901 & $\begin{array}{l}\text { Late flowering, more plant height, maximum } \\
\text { 100-seed weight, maximum harvest index and } \\
\text { highest seed yield per plant. }\end{array}$ \\
\hline
\end{tabular}


Table.2 Average intra (bold) and inter-cluster distance based on corresponding $\mathrm{D}^{2}$ values

\begin{tabular}{|c|c|c|c|c|c|c|c|c|}
\hline Clusters & I & II & III & IV & V & VI & VII & VIII \\
\hline I & $\mathbf{1 5 3 . 1 4}$ & 587.30 & 368.84 & 293.60 & 371.89 & 405.48 & 419.68 & 507.40 \\
\hline II & & $\mathbf{1 9 8 . 4 8}$ & 1437.00 & 1148.80 & 1385.10 & 947.34 & 466.22 & 543.70 \\
\hline III & & & $\mathbf{0 . 0 0}$ & 281.18 & 183.51 & 447.55 & 939.50 & 1104.00 \\
\hline IV & & & & $\mathbf{0 . 0 0}$ & 125.62 & 645.91 & 822.90 & 463.31 \\
\hline V & & & & & $\mathbf{0 . 0 0}$ & 757.10 & 1061.83 & 848.71 \\
\hline VI & & & & & & $\mathbf{0 . 0 0}$ & 220.89 & 953.10 \\
\hline VII & & & & & & & $\mathbf{0 . 0 0}$ & 654.88 \\
\hline VIII & & & & & & & & $\mathbf{0 . 0 0}$ \\
\hline
\end{tabular}

Table.3 Mean values of genotypes present in different clusters for different characters

\begin{tabular}{|c|c|c|c|c|c|c|c|c|c|c|c|c|}
\hline Clusters & $\begin{array}{c}\text { Days to } \\
\text { 50\% } \\
\text { Flowering }\end{array}$ & $\begin{array}{c}\text { Days to } \\
\text { Maturity }\end{array}$ & $\begin{array}{c}\text { Plant } \\
\text { Height }\end{array}$ & $\begin{array}{c}\text { No. of } \\
\text { branches } \\
\text { /plant }\end{array}$ & $\begin{array}{c}\text { No. of } \\
\text { pods } \\
\text { /plant }\end{array}$ & $\begin{array}{c}\text { No. of } \\
\text { seeds } \\
\text { /pod }\end{array}$ & $\begin{array}{c}\text { Pod } \\
\text { length }\end{array}$ & $\begin{array}{c}\text { 100- } \\
\text { Seed } \\
\text { Weight }\end{array}$ & $\begin{array}{c}\text { PC } \\
\text { Biological } \\
\text { yield } \\
\text { /plant }\end{array}$ & $\begin{array}{c}\text { HI } \\
\text { Seed } \\
\text { yield } \\
\text { /plant }\end{array}$ \\
\hline I & 46.75 & 70.36 & 51.42 & 2.71 & 9.56 & 8.03 & 12.26 & 12.75 & 22.93 & 36.88 & 11.86 & 4.28 \\
\hline II & 46.36 & 70.25 & 88.27 & 2.33 & 11.23 & 7.57 & 12.08 & 12.17 & 22.93 & 40.52 & 13.58 & 5.44 \\
\hline III & 47.00 & 71.00 & 25.66 & 4.33 & 14.80 & 7.13 & 14.44 & 11.50 & 22.76 & 40.87 & 11.64 & 4.76 \\
\hline IV & 46.67 & 69.67 & 35.16 & 2.40 & 5.73 & 7.13 & 14.03 & 12.64 & 22.23 & 27.53 & 20.05 & 5.52 \\
\hline V & 47.33 & 71.00 & 25.65 & 3.47 & 4.60 & 6.00 & 20.36 & 14.38 & 22.03 & 27.20 & 13.04 & 3.55 \\
\hline VI & 44.67 & 69.67 & 46.91 & 2.87 & 12.20 & 8.07 & 11.55 & 12.85 & 22.55 & 62.40 & 6.58 & 4.10 \\
\hline VII & 49.00 & 71.00 & 67.66 & 2.13 & 3.80 & 6.00 & 10.04 & 9.88 & 20.63 & 56.60 & 4.20 & 2.38 \\
\hline VIII & 49.00 & 69.33 & 70.57 & 2.67 & 8.63 & 6.73 & 13.80 & 16.32 & 22.80 & 29.40 & 28.55 & 8.39 \\
\hline
\end{tabular}

Cluster I having 12 genotypes showed highest mean for protein content (22.93) and ranked $2^{\text {nd }}$ for mean value of number seeds/pod (8.03). Mean values for number of pods/plant (9.56) and number of branches/plant (2.71) ranked $4^{\text {th }}$. Cluster II with 12 genotypes recorded highest mean value for plant height (88.27) and protein content (22.93). It had second lowest mean for days to $50 \%$ flowering (46.36) which showed early flowering along with moderate number of pods/plant (11.23), number of seeds/pod (7.57), harvest index (13.58) and seed yield/plant (5.44). Cluster III being monogenotypic (Sadabahar-12) had highest mean for number of branches/plant (4.33) and number of pods/plant (14.80). It ranked $2^{\text {nd }}$ in pod length (14.44) and $3^{\text {rd }}$ in protein content (22.76) and biological yield/plant (40.87). Cluster IV with single genotype (PGCP-68) obtained $2^{\text {nd }}$ position for the mean values of harvest index (20.05) and seed yield/plant (5.52). Genotype belongs to this cluster had second lowest mean for days to maturity (69.67). Cluster V having single genotype (Kashi kanchan) had $1^{\text {st }}$ rank for pod length (20.36). It ranked $2^{\text {nd }}$ for number of branches/plant (3.47) and 100-seed weight (14.38) and ranked $7^{\text {th }}$ for number of pods/plant (4.60) and seed yield/plant (3.55). It reported lowest mean value for biological yield/plant (27.20). Cluster VI being monogenotypic (GC-6) showed lowest mean for days to 50 per cent flowering (44.67), hence was earliest in flowering. It also ranked $1^{\text {st }}$ in number of seeds/pod (8.07) and biological yield/plant $(62.40)$ and ranked $2^{\text {nd }}$ in number of pods/plant (12.20). This cluster ranked $7^{\text {th }}$ in pod length (11.55) and harvest index (6.58). Cluster VII was also monogenotypic (KBC-2) and it ranked $2^{\text {nd }}$ in biological yield/plant $(56.60)$ and had $3^{\text {rd }}$ 
highest mean in plant height (67.66). This cluster was late in flowering (49.00) and mean values for number of branches/plant (2.13), pod length (10.04), 100-seed weight (9.88), harvest index (4.20) and seed yield/plant (2.38) were lowest. Cluster VIII with single genotype (TC-901) observed highest mean estimates for 100-seed weight (16.32), harvest index (28.55) and seed yield/plant (8.39). It had lowest mean value for days to maturity (69.33) hence early maturing. It ranked $5^{\text {th }}$ in number of pods/plant (8.63) and number of seeds/pod (6.73) and ranked $6^{\text {th }}$ in biological yield/plant (29.40).

Contribution of individual character towards divergence was highest for plant height $(60.23 \%)$ followed by biological yield/plant (20.69\%), 100-seed weight $(5.75 \%)$ and harvest index (5.29\%). Contribution of various characters towards divergence in cowpea was earlier reported by Jain et al.(2006) for number of pods/plant and Jogdhande et al., (2016) for plant height.

In conclusion the availability of considerable genetic divergence between the genotypes tested in present experiment indicated that these genotypes of cowpea might represent good source for sorting out the diverse parents for hybridization plan intended at isolating desirable combination for seed yield as well as other desirable characters. On account of mean performance of different clusters, cluster II and cluster VIII were performing quite well for most of the characteristics studied. Highest inter cluster distance was reported between cluster II and cluster III along with cluster II and cluster V and cluster II and cluster IV. Thus, the crossing between the genotypes from most diverse clusters could be used for transgressive segregants.

\section{Acknowledgement}

Dr. A.K. Parihar, Scientist Sr. Scale, Division of Crop Improvement, ICAR-IIPR, Kanpur and ARS, SKRAU, Bikaner provided valuable cowpea genotypes for research work.

\section{References}

Jain, P., Saini, M.L. and Arrora, R.N. (2006). Genetic divergence in cowpea. Forage Res., 32: 12-14.

Jogdhande Srinivas, Vijay S. Kale, Nagre, P.K. and Samrat Meshram (2016). Genetic divergence studies in cowpea. Int. J. Agric. Sci. and Res., 6 (3): 97104.

Praveena, V.S., Abraham, M. and Kumar, V. (2019). Genetic divergence studies in fodder cowpea [Vigna unguiculata (L.) Walp.] using $\mathrm{D}^{2}$ statistics. Forage Res., 44 (4): 230-236.

Rao, C.R. (1952). Advanced statistical methods in Biometrical Research. John Willey and Sons. Inc., New York.

Vavilapalli, S. K., Celine, V. A. and Sreelathakumai, I. (2014). Genetic divergence analysis in vegetable cowpea [Vigna unguiculata subsp. unguiculata(L.) Walp.] genotypes. Legume Genomics and Genetics, 5(2).

\section{How to cite this article:}

Navreet Kaur Rai, A. K. Sharma, A. K. Parihar, Sangeeta Pal and Ravina Beniwal. 2020. Genetic Divergence Analysis in Cowpea [Vigna unguiculata (L.) Walp.]. Int.J.Curr.Microbiol.App.Sci. 9(12): 2241-2244. doi: https://doi.org/10.20546/ijcmas.2020.912.264 